\title{
Relationship Among In-Situ and Laboratory Determinations of Soil Field Capacity Under Arid Conditions
}

Ahmed G.M. Hesseen ${ }^{1^{*}}$,Shaimaa H. Abd-Elrahman ${ }^{2}$,Mohamed E. Galal ${ }^{2}$, Ayman F. Abou-Hadid , $^{3}$

${ }^{1}$ Arid Lands Department, Faculty of Agric, Ain Shams University, P.O. Box 68, HadayekShoubra 11241, Cairo, Egypt

${ }^{2}$ Soils and Water Dept, Faculty of Agriculture, Ain Shams University, P.O. Box 68, HadayekShoubra 11241, Cairo, Egypt

${ }^{3}$ Horticulture Dept., Faculty of Agriculture, Ain Shams University, P.O. Box 68, HadayekShoubra 11241, Cairo, Egypt

*Correspondence Ahmed Hesseen

(E-mail: ahmedgamel2002@yahoo.com)

Received: $02 / 09 / 2021$

Revised: 25/09/2021

Accepted: $26 / 09 / 2021$

Published: $28 / 09 / 202$

\begin{abstract}
To investigate the relationship among field capacity (FC) determined in-situ and laboratory determinations of soil moisture content of different soil textural classes under different applied pressures, one hundred and sixty-eight of surface samples were collected. The collected samples were classified to seven groups based on the USDA texture triangle. Simulated field determinations of in-situ FC were done and the obtained results revealed that the elapsed time to reach FC and the values of soil moisture tension differed according to soil textural class. Generally, increasing water-holding pores and/or fine capillary pores increased both moisture tension at $\mathrm{FC}\left(\mathrm{h}_{\mathrm{fc}}\right)$ and elapsed time to reach it after heavy irrigation $\left(t_{\mathrm{fc}}\right)$. Sandy and loamy sand soils showed the highest significant correlation coefficient between in- situ FC and soil water content balanced with 60 mbar of the applied pressure whereas sandy loam soil achieves the highest significant value of correlation coefficient at 100 mbar of the applied pressure. Significant correlation coefficients among FC - in situ - and soil moisture content balanced with 330 mbar of the applied pressure of the other soil textural classes under study were found.
\end{abstract}

Keywords: Field capacity; Soil moisture content; Soil water depletion rate; Soil moisture characteristics data; Pore size distribution. 


\section{Introduction}

Under arid conditions, irrigated agriculture became a must. So calculating available water for plant is the first step in irrigation process. Available water for plant is easy to calculate, but needs accurate estimates of both FC and permanent wilting point to be helpful in irrigation scheduling.

FC is a character of the soil which usually used in soil hydraulic investigations and applications. The original definition of FC introduced by (Veihmeyer and Hendrickson 1949) and slightly modified in the (Glossary of Soil Science Terms 1984) as: "field capacity is the amount of water remaining in soil two or three days after having been wetted and after free drainage is negligible".

FC concept assumes that the water removed from the soil profile only by gravity, not through evaporation or the transpiration of plants (Hillel 2003).

The relatively constant value of soil moisture content at field capacity is not always assured; and depends on some characters of the soil profile, the presence of impeding layers or a water table which affect the rate and extent of water redistribution (Or and Warrick 2002).

Generally, Galal 2000 reported that using predefined values of pressure heads to be the limits of readily available water is an illogic procedure. So; depending on the shape of the water retention curve in assigning these limits is a perfect and logical solution because the soil moisture release curve reflects the real behavior of soil moisture under different pressure heads. He explained that, in the first part of the soil moisture release curve, the gravitational potential is the dominant force, which affects the behavior of soil moisture. While in the second part capillarity acts as a major force that controls the behavior of soil moisture and in the third one capillarity and adsorption forces are dominant in highpressure head values.
Methods of FC determination include field and laboratory methods. Concerning field determinations there are many approaches and estimates. FC is reached approximately after 1 to 2 days after sufficient rain or irrigation when internal drainage becomes essentially negligible and water content reaches a near-constant value (Or and Warrick 2002; Hillel 2003).

Kirkham 2005 proposed that soil moisture tension at $\mathrm{FC} h_{\mathrm{fc}} \approx-100$ mbar for coarse texture soils and $h_{\mathrm{fc}} \approx-330$ mbar for heavy-textured soils. Consequently, using these two tension heads at FC, the largest water-filled pores in coarse textured soil is about $15 \mu \mathrm{m}$ while the largest water-filled pores in heavy-textured soil are about $4 \mu \mathrm{m}$.

Generally Santra et al., 2018 reported that soil moisture content at FC occurs in the field after 2-3 days of free drainage from saturation.

Concerning laboratory method of FC determination, various laboratory methods have been suggested for the determination of soil FC. FC is commonly evaluated in a laboratory setting as the moisture content of soil samples at a specific matric potential.

Cassel and Nielsen 1986 reported that a wide range of matric potentials (from -2.5 $\mathrm{kPa}$ to $-50 \mathrm{kPa}$ ) has been used for this purpose, and suctions of $5 \mathrm{kPa}, 6 \mathrm{kPa}, 10$ $\mathrm{kPa}$, and $33 \mathrm{kPa}$ are more common choices.

The measurement of water content at specific points of the soil-water characteristic curve may be the most widespread. The determination of the water content at suctions of $60 \mathrm{hPa}, 100 \mathrm{hPa}, 300 \mathrm{hPa}$ or 333 $\mathrm{hPa}$ is common (Lipsius 2002).

Shokri and Lehmann; Or 2008 stated that usually the soil is considered to be at FC when the water potential in the soil is at -33 $\mathrm{kPa}$. So, soil FC is mostly determined in the laboratory by the pressure set method and the value of the FC is represented by the balance of water with the tension of 6 up to $33 \mathrm{kPa}$, depending on the texture, structure and content of organic matter in the soil. 
Various researchers proposed different values of water potential in the soil at FC, including $\psi_{\mathrm{fc}}=20,10$, and $5 \mathrm{kPa}$ such as (Romano and Santini, 2002; Nemes et al., 2011 and Silva et al., 2014).

A laboratory method was performed by Galal 2000 to define the upper and lower limits of easily available water in the soil based on the actual behavior of water in the soil which can be noticeable at the water retention curve.

\section{Materials and Methods}

One hundred and sixty-eight of both disturbed and undisturbed surface soil samples $(0-30 \mathrm{~cm}$ depth) were collected. The collected soil samples were analyzed using the standard methods described by Dane and Topp, 2002. One soil sample was chosen to represent each textural class, the main soil properties of the selected samples are presented in Tables 1 and 2.

Table 1. Some physical and hydraulic properties of the selected soil samples

\begin{tabular}{|c|c|c|c|c|c|c|c|c|}
\hline \multirow[t]{2}{*}{ No. } & \multicolumn{4}{|c|}{ * Particle size distribution \% } & \multirow[t]{2}{*}{ Textural class } & \multirow[t]{2}{*}{$\rho_{b} \mathbf{g} / \mathrm{cm}^{3}$} & \multirow[t]{2}{*}{$f \%$} & \multirow{2}{*}{$\begin{array}{c}\mathrm{Ks} \\
\mathbf{c m} / \mathbf{h}\end{array}$} \\
\hline & $\begin{array}{c}\text { Coarse } \\
\text { Sand }\end{array}$ & $\begin{array}{l}\text { Fine } \\
\text { Sand }\end{array}$ & Silt & Clay & & & & \\
\hline 1 & 78.8 & 13.3 & 5.7 & 2.2 & Sand & 1.65 & 37.7 & 452.6 \\
\hline 2 & 65.7 & 14.9 & 4.1 & 12.3 & Loamy Sand & 1.46 & 44.9 & 132.5 \\
\hline 3 & 53.8 & 12.2 & 21.6 & 15.4 & Sandy Loam & 1.42 & 46.4 & 68.4 \\
\hline 4 & 24.5 & 21.5 & 21.6 & 28.4 & Sandy clay loam & 1.36 & 48.7 & 15.8 \\
\hline 5 & 7.3 & 40.5 & 11.5 & 40.7 & Sandy clay & 1.32 & 50.2 & 7.4 \\
\hline 6 & 9.4 & 27.1 & 31.3 & 32.2 & Clay Loam & 1.29 & 51.3 & 3.6 \\
\hline 7 & 1.7 & 21.8 & 31.4 & 45.1 & Clay & 1.24 & 53.2 & 1.9 \\
\hline * & Accor & to th & S & le & ral class a & $g$ to th & DA & le \\
\hline$f$ & Total 1 & osity & ning & 1 part & ensity $=2.65$ & & & \\
\hline Ks & Satura & hydra & con & ivity & & & & \\
\hline
\end{tabular}

The points of soil moisture retention data were measured by sand box, the pressure plate apparatus with applied pressures of $20,33,60,100,500,1000$, $3000,5000,10000$ and 15000 mbar and the obtained data were fitted to the logarithmic equation, Table 3.

Pore size distribution was calculated from soil moisture retention data according to Dane and Topp 2002 and presented in Table 4.

Israelsen and Wiley 1950 reported that the essential conditions to be observed in determining the FC of soils in the field are saturate the soil profile to the depth under study by adding an excess of irrigation water, minimize surface evaporation losses, eliminate transpiration losses by working on a non cultivated fields and select plots containing uniform and free draining soil, then record the rate of soil water depletion.

To get soil water depletion rate and FC (in-situ), the abovementioned conditions were simulated. Each soil sample was packed in a plastic cup (with perforated base) of $6 \mathrm{~cm}$ height and $12 \mathrm{~cm}$ upper diameter, 10 $\mathrm{cm}$ lower diameter up to compose its tabulated bulk density \pm 0.05 , in Table 1 . Each treatment was replicated four times.

Soil cups were saturated with tap water, each cup was covered with a lid and leaved to drain the excess water through the perforated pored base. Cups weight were recorded to determine water depletion from the soil after 1, 6, 12, 24, 48, 72 and 96 hours up to equilibrium, where no change in cups weight and no drain water from plastic cups. The obtained data of soil water depletion was used to formulate $\theta(t)$ curve and extract the 
values of soil moisture content at field capacity $\left(\theta_{\mathrm{fc}}\right)$ (Table 5).

Table 2. Some chemical properties of the selected soil samples

No.

\begin{tabular}{|c|c|c|c|c|c|c|c|c|c|c|c|c|}
\hline \multirow[t]{2}{*}{ No. } & \multirow[b]{2}{*}{ 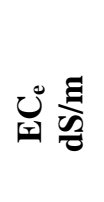 } & \multirow[b]{2}{*}{$\underset{*}{*}$} & \multirow[b]{2}{*}{$\begin{array}{l}0 \\
\tilde{e} \\
\tilde{J}\end{array}$} & \multirow[b]{2}{*}{$\begin{array}{l}\stackrel{0}{0} \\
\sum_{0} \\
* \\
*\end{array}$} & \multicolumn{4}{|c|}{ Soluble cautions meq/l } & \multicolumn{4}{|c|}{ Soluble anions meq/l } \\
\hline & & & & & $\stackrel{+}{4}$ & $\stackrel{+}{\mathbf{z}}$ & $\stackrel{+}{+\infty 00}_{\sum}^{+}$ & שٓ & $\dot{ப}$ & "ః & $\overbrace{0}^{\prime}$ & రి \\
\hline 1 & 2.7 & 7.8 & 3.4 & 0.00 & 0.3 & 12.6 & 8.7 & 5.4 & 16.8 & 5.8 & 4.4 & nd \\
\hline 2 & 2.1 & 8.2 & 4.2 & 0.00 & 0.2 & 8.5 & 6.3 & 6.0 & 10.1 & 7.4 & 3.5 & nd \\
\hline 3 & 2.7 & 8.1 & 5.1 & 0.16 & 0.3 & 11.8 & 4.6 & 10.3 & 15.8 & 6.2 & 5 & nd \\
\hline 4 & 1.8 & 7.7 & 2.8 & 0.75 & 0.5 & 6.8 & 3.8 & 6.9 & 10.4 & 4.6 & 3 & nd \\
\hline 5 & 2.3 & 7.8 & 2.2 & 0.84 & 0.4 & 12.6 & 3.9 & 6.1 & 15.4 & 4.5 & 3.1 & $\mathrm{nd}$ \\
\hline 6 & 3.6 & 7.7 & 1.8 & 0.77 & 1.1 & 19.2 & 6.7 & 9 & 22.3 & 6.4 & 7.3 & $\mathrm{nd}$ \\
\hline 7 & 2.1 & 7.5 & 1.6 & 0.78 & 0.8 & 11.8 & 3.4 & 5 & 12.6 & 3.7 & 4.7 & $\mathrm{nd}$ \\
\hline$*$ & $\begin{array}{l}\text { Soil } \\
\text { Orga }\end{array}$ & $n$ & & & & & & & & & & \\
\hline
\end{tabular}

Using the fitted equation of soil moisture characteristics data, which presented in Table 3, soil moisture tension at $\mathrm{FC}\left(\mathrm{h}_{\mathrm{fc}}\right)$ and the elapsed time to reach it $\left(\mathrm{t}_{\mathrm{fc}}\right)$ were calculated for soil samples of each textual class and the mean values of each textural class are presented in Table 6.

To obtain the relationship between soil water content at saturation and at FC, under different soil textural classes, a trial was conducted as follow:

Mathematically, according to Taylor and Ashcroft 1972 the intercept of each equation represent water saturation point of the pertinent soil sample, where:

$\theta=\mathrm{a} * \mathrm{~h}^{-\mathrm{b}}$

$\ln (\theta)=-b \ln (h)+\ln (a)$

(1)

at saturation $\mathrm{h} \approx 0$

- $\mathrm{b} \ln (\mathrm{h}) \approx 0$

(2)

From equations (1) and (2)

$\ln (\theta)=\ln (\mathrm{a})$

$\theta=$ a with ............. $0.990 \geq \mathrm{R}^{2} \geq 0.951$

Therefore, both values of which denote soil moisture content at saturation (saturation point), and in-situ FC were used to get estimation coefficient for soil textural classes under study, as follow:

Estimation coefficient $=$ in-situ $\mathrm{FC}\left(\theta_{\mathrm{FC}}\right) /$ saturation point.

The aforementioned coefficient was calculated for each soil textural class individually.

Table 8 shows arithmetic means, standard deviation and confidence intervals at 0.95 significance level of both soil saturation point and moisture content at insitu FC of different soil textural classes.

The statistical determination was used to get some statistical parameters e.g., arithmetic mean, standard deviation, and standard error, whereas the statistical analysis was used to identify the significance of differences among the field determination of in - situ FC on one side and the soil moisture content determined under different pressures - laboratory determination-on the other one (Table 7) using the method of Steel and Torrie 1980. The data were also subjected to simple linear and non-linear regression analyses. The coefficients of determination (denoted by $\mathrm{R}^{2}$ ) of soil moisture retention and depletion were verified. The coefficient of determination 
$\left(\mathrm{R}^{2}\right)$ is calculated to express how close the data are to the fitted regression line (Barten 1987).

\section{Results and Discussion}

Data of Table 1 reveal that the selected soil samples representing seven textural classes, and there are no deviative values of both physical and chemical properties of the selected soil samples, according to Singh (1980).

Table 3 shows the fitted equations of water characteristics data of the selected soil samples. From the foregoing Table, soil moisture retention data is strongly affected by soil texture, where the slope of $\theta(h)$ equation represents the depletion rate of soil water content as the suction increases. The values of depletion rate (denote with $b$ ) are 0.03 for sand, loamy sand and sandy loam textural classes, while it equals -0.02 for sandy clay loam and sandy clay textural classes. The values of depletion rate of $\theta(\mathrm{h})$ equation equals -0.01 for both clay loam and clay textural classes.

Table 3. Fitted equations of moisture characteristics data $\theta(h)$ of the selected soil samples

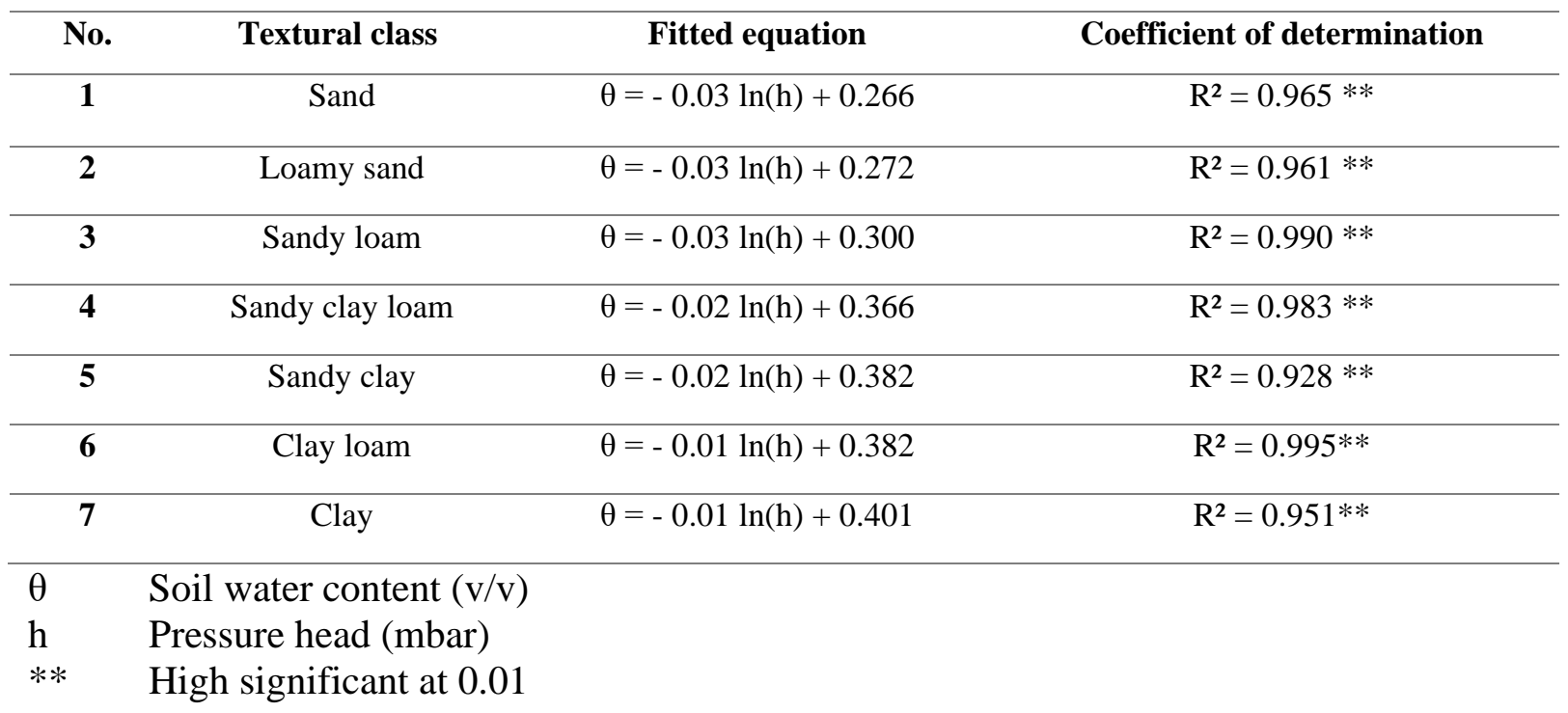

Table 4 reveals that quickly drainable pores of the selected soil samples decreased while both water holding pores and fine capillary ones in the studied soils of different textural classes increased in this order, sand, loamy sand, sandy loam, sandy clay loam, sandy clay, clay loam, and clay.

Table 4. Pore size distribution of the selected soil samples.

\begin{tabular}{cccccc}
\hline No. & Textural class & QSP & SDP & WHP & FCP \\
\hline $\mathbf{1}$ & Sand & 0.229 & 0.056 & 0.081 & 0.011 \\
$\mathbf{2}$ & Loamy sand & 0.221 & 0.031 & 0.095 & 0.019 \\
\hline $\mathbf{3}$ & Sandy loam & 0.215 & 0.041 & 0.111 & 0.032 \\
\hline $\mathbf{4}$ & Sandy clay loam & 0.181 & 0.012 & 0.144 & 0.144 \\
\hline $\mathbf{5}$ & Sandy clay & 0.106 & 0.012 & 0.156 & 0.181 \\
\hline $\mathbf{6}$ & Clay loam & 0.105 & 0.011 & 0.158 & 0.192 \\
\hline $\mathbf{7}$ & Clay & 0.101 & 0.011 & 0.154 & 0.196 \\
\hline
\end{tabular}



QSP Quickly drainable pores
Diameter $(\mu \mathrm{m}) \geq 28.8$
SDP Slowly drainable pores
Diameter $(\mu \mathrm{m}) 28.8$ - 8.62
WHP Water holding pores
Diameter $(\mu \mathrm{m}) 8.62$ - 0.19
FCP Fine capillary pores
Diameter $(\mu \mathrm{m}) \leq 0.19$

Results in Table 5 show data of simulation of in - situ determination of FC $\left(\theta_{\mathrm{fc}}\right)$ of the studied soil samples and the fitted equations of water depletion data of the selected soil samples and their coefficients of determination. The slope of this equation denotes the depletion rate of soil water under gravity action as a function of time $\theta(\mathrm{t})$ after excess irrigation. The obtained results show that fine textured soil samples i.e clay loam and clay soils have the lowest values of the slope of the fitted equations, while course textured soil samples i.e sandy, loamy sand and sandy loam have the highest ones. The fitted equations of all soil samples have negative values of the slope, which indicate that soil water reach to equilibrium under gravity force in coarse - textured soil samples sooner than in heavy - textured ones.

Table 5. Fitted equations of moisture depletion data $\theta(\mathrm{t})$ of the selected soil samples

\begin{tabular}{cccc}
\hline No. & Textural class & Fitted equation & Coefficient of determination \\
\hline $\mathbf{1}$ & Sand & $\theta=-0.03 \ln (\mathrm{t})+0.290$ & $\mathrm{R}^{2}=0.889 * *$ \\
\hline $\mathbf{2}$ & Loamy sand & $\theta=-0.03 \ln (\mathrm{t})+0.294$ & $\mathrm{R}^{2}=0.883 * *$ \\
\hline $\mathbf{3}$ & Sandy loam & $\theta=-0.03 \ln (\mathrm{t})+0.319$ & $\mathrm{R}^{2}=0.925 * *$ \\
\hline $\mathbf{4}$ & Sandy clay loam & $\theta=-0.02 \ln (\mathrm{t})+0.328$ & $\mathrm{R}^{2}=0.859 * *$ \\
\hline $\mathbf{5}$ & Sandy clay & $\theta=-0.02 \ln (\mathrm{t})+0.346$ & $\mathrm{R}^{2}=0.907 * *$ \\
\hline $\mathbf{6}$ & Clay loam & $\theta=-0.01 \ln (\mathrm{t})+0.408$ & $\mathrm{R}^{2}=0.877 * *$ \\
\hline $\mathbf{7}$ & Clay & $\theta=-0.01 \ln (\mathrm{t})+0.441$ & $\mathrm{R}^{2}=0.889 * *$ \\
\hline $\boldsymbol{t}$ & $\begin{array}{l}\text { Soil water content }(\mathrm{v} / \mathrm{v}) \\
\mathrm{t}\end{array}$ & $\begin{array}{l}\text { Elapsed time (hour) } \\
\text { High significant at } 0.01\end{array}$ &
\end{tabular}

Table 5 reveals also that, both sandy and loamy sand soils reached FC at about 60 mbar soil moisture tension $(60 \pm 6$ mbar) after 33.11 and 34.22 hours from ending excess irrigation, respectively While sandy loam one reached to FC at about 86 mbar soil moisture tension after 39.09 hours from irrigation. The others soils reached FC at about 330 mbar soil moisture tension $( \pm 30$ mbar) where the values of soil moisture tension were $314.19,330.29,330.23$ and 365.03 mbar of sandy clay loam, sandy clay, clay loam and clay soils, respectively, where the aforementioned four soils needed 46.99, $54.59,81.45$, and 90.01 hours to reach their FC, respectively. These findings may be due to the dominance of macropores (quickly drainable pores) in the coarse-textured soil samples and in contrary to fine-textured one, where fine capillary pores are dominant. Generally, increasing water holding pores and/or fine capillary pores, both soil moisture tension at $\mathrm{FC}\left(\mathrm{h}_{\mathrm{fc}}\right)$ and elapsed time to reach it after the end of irrigation (Or and Warrick 2002; Hillel 2003).

Table 7 shows the coefficients of simple correlation among the value of simulated in - situ FC and soil moisture contents under different applied pressures of different soil textural classes. The obtained data reveal that in the case of sandy soil samples, the highest significant value of the 
correlation coefficient was obtained between in - situ FC $\left(\theta_{\mathrm{fc}}\right)$ and soil moisture content balanced with 60 mbar of applied pressure. Also, the loamy sand soil samples follow the same trend of sand soil samples, where the highest significant value of the correlation coefficient, was between in situ FC $\left(\theta_{\mathrm{fc}}\right)$ and soil moisture content balanced with 60 mbar of the applied pressure, whereas the sandy loam soil samples achieve the highest significant value of correlation coefficient at 100 mbar of the applied pressure. Noteworthy, the abovementioned correlation coefficients concerning sand, loamy sand, and sandy loam textural classes are highly significant and equal to $0.8734,0.8876$, and 0.9077, respectively. Results in Table 7 reveals also that the calculated values of the correlation coefficient between in - situ FC $\left(\theta_{\mathrm{fc}}\right)$ and soil moisture content balanced with $330 \pm 30$ mbar of the applied pressure of sandy clay loam, sandy clay, clay loam and clay soil samples are highly significant and equal 0.8775 , $0.9549,0.8983$ and 0.9560 , respectively.

Table 6. Mean values of simulated field determinations of both soil moisture content and tension at field capacity in-situ and elapsed time to reach it.

\begin{tabular}{|c|c|c|c|c|c|}
\hline No. & Soil texture & Number of soil samples & $\theta_{\mathrm{fc}}$ & $\mathbf{h}_{\mathrm{fc}}$ & $t_{f c}$ \\
\hline 1 & Sand & 28 & 0.185 & 54.59 & 33.11 \\
\hline 2 & Loamy sand & 26 & 0.188 & 66.68 & 34.22 \\
\hline 3 & Sandy loam & 26 & 0.209 & 85.62 & 39.09 \\
\hline 4 & Sandy clay loam & 19 & 0.251 & 314.19 & 46.99 \\
\hline 5 & Sandy clay & 18 & 0.266 & 330.29 & 54.598 \\
\hline 6 & Clay loam & 21 & 0.324 & 330.23 & 81.45 \\
\hline 7 & Clay & 30 & 0.342 & 365.03 & 90.01 \\
\hline$\theta_{\mathrm{fc}}$ & Soil moist & ntent at field capacity & & & \\
\hline$h_{f c}$ & Soil moist & nsion at field capacity & & & \\
\hline$t_{\mathrm{fc}}$ & Elapsed tiı & reach field capacity & & & \\
\hline
\end{tabular}

These findings concluded that as micropores (Diameter $\leq 8.62 \mu \mathrm{m}$ ) are the dominant pores in the soil, the value of the applied pressure balanced with soil water at FC, increased. On the contrary, the dominance of macropores (Diameter $\geq 8.62$ $\mu \mathrm{m})$ in the soil led to a decrease of the applied pressure balanced with soil water at FC (Dane and Topp 2002).

Generally, data of this table confirm that there is no single value of the applied pressure to get FC using laboratory determination, but it differs according to soil texture, structure, clay mineralogy, organic matter and bulk density (O'Sullivan and

Ball 1993). This conclusion coincides also with the conclusion of Table 6 .

Table 8 shows arithmetic means standard deviation and confidence intervals of both soil saturation point and moisture content at in - situ FC of different textural classes. The ratio between simulated in-situ
FC $\left(\theta_{\mathrm{fc}}\right)$ and fitted water saturation point was calculated for all soils under study. Soil water content at in-situ FC $\left(\theta_{\mathrm{fc}}\right)$ represents $69.55,69.18,69.66,68.58,69.63,84.82 \%$ and $85.28 \%$ of water saturation point of sand, loamy sand, sandy loam, sandy clay loam, sandy clay, loamy clay and clay, respectively.

Results in Table 8 shows also the estimated values of FC using the suggested coefficient for each soil textural class under study. Generally, soil moisture content at FC $\left(\theta_{\mathrm{fc}}\right)$ can be estimated as 0.70 of fitted saturation point for coarse and medium textured soils e.g., sand, loamy sand, sandy loam, sandy clay loam and sandy clay, while it can be estimated with 0.85 of fitted saturation point for heavy textured soils e.g., loamy clay and clay.

Fig 1 shows the relationship between actual in-situ soil FC $\left(\theta_{\mathrm{fc}}\right)$ and estimated one of the studied soil samples with different 
textural classes calculated using the saturation point of the studied soil textured estimation coefficient 0.70 for coarse and classes. The simple correlation coefficient medium textured soils and 0.85 for heavy between actual in-situ soil FC and estimated textured soils. The coefficient was obtained ones of the studied soil samples with by dividing the in-situ $\mathrm{FC}\left(\theta_{\mathrm{fc}}\right)$ with a different textural classes equals 0.9996

Table 7. Simple correlation coefficient among in-situ field capacity and soil moisture content under different values of pressure heads of different soil textural classes.

\begin{tabular}{cccccccc}
\hline \multirow{2}{*}{$\begin{array}{c}\text { No. } \begin{array}{c}\text { Number of } \\
\text { soil samples }\end{array} \\
\end{array}$} & & Textural class & \multicolumn{5}{c}{ Pressure head (mbar) } \\
\cline { 4 - 7 } & & & $\mathbf{2 0}$ & $\mathbf{6 0}$ & $\mathbf{1 0 0}$ & $\mathbf{3 3 0}$ & $\mathbf{5 0 0}$ \\
\hline $\mathbf{1}$ & 28 & Sand & $0.7496 *$ & $0.8723 * *$ & $0.6565 *$ & 0.4959 & 0.4012 \\
\hline $\mathbf{2}$ & 26 & Loamy sand & 0.5059 & $0.8876 * *$ & 0.3619 & 0.3577 & 0.3535 \\
\hline $\mathbf{3}$ & 26 & Sandy loam & 0.4827 & 0.5347 & $0.9077 * *$ & 0.4347 & 0.3346 \\
\hline $\mathbf{4}$ & 19 & Sandy clay loam & 0.3885 & 0.5147 & 0.5991 & $0.8774 * *$ & 0.5282 \\
\hline $\mathbf{5}$ & 18 & Sandy clay & 0.3619 & 0.4111 & 0.3346 & $0.9549 * *$ & 0.4123 \\
\hline $\mathbf{6}$ & 21 & Clay loam & 0.3924 & 0.3975 & 0.3564 & $0.8983 * *$ & 0.3240 \\
\hline $\mathbf{7}$ & 30 & Clay & 0.6723 & 0.6663 & 0.4110 & $0.9560 * *$ & 0.5339 \\
\hline
\end{tabular}

Significant at $0.05^{* *}$ High significant at 0.01

Table 8. Arithmetic means, standard deviation and confidence intervals of both saturation point and soil moisture content at in-situ field capacity of different textural classes.

\begin{tabular}{|c|c|c|c|c|}
\hline Textural class & $\begin{array}{l}\text { Number of soil } \\
\text { samples }\end{array}$ & $\begin{array}{l}\text { Saturation point from } \\
(\theta) h \text { fitted equation }\end{array}$ & $\begin{array}{l}\text { Theta at in-situ } \\
\text { FC }\left(\theta_{\mathrm{fc}}\right)\end{array}$ & $\begin{array}{c}\text { Estimated } \\
\text { Theta at FC }\end{array}$ \\
\hline \multirow[t]{2}{*}{ Sand } & 28 & $0.266(0.0211)$ & $0.1850(0.0093)$ & 0.1862 \\
\hline & & $0.27381-0.2582$ & $0.1884-0.1815$ & \\
\hline \multirow[t]{2}{*}{ Loamy sand } & 26 & $0.272(0.0231)$ & $0.1880(0.0087)$ & 0.1904 \\
\hline & & $0.2808-0.2631$ & $0.1913-0.1846$ & \\
\hline \multirow[t]{2}{*}{ Sandy loam } & 26 & $0.300(0.0306)$ & $0.2090(0.0092)$ & 0.2100 \\
\hline & & $0.3117-0.2882$ & $0.2125-0.2054$ & \\
\hline \multirow[t]{2}{*}{ Sandy clay loam } & 19 & $0.366(0.0328)$ & $0.2510(0.0102)$ & 0.2562 \\
\hline & & $0.3807-0.3512$ & $0.2556-0.2464$ & \\
\hline \multirow[t]{2}{*}{ Sandy clay } & 18 & $0.382(0.0338)$ & $0.2660(0.0113)$ & 0.2674 \\
\hline & & $0.3976-0.3664$ & $0.2712-0.2607$ & \\
\hline \multirow[t]{2}{*}{ Clay loam } & 21 & $0.382(0.0288)$ & $0.3240(0.0142)$ & 0.3247 \\
\hline & & $0.3943-0.3697$ & $0.3300-0.3179$ & \\
\hline \multirow[t]{2}{*}{ Clay } & 30 & $0.401(0.0382)$ & $0.3420(0.0161)$ & 0.3408 \\
\hline & & $0.4146-0.3873$ & $0.3477-0.3362$ & \\
\hline
\end{tabular}

Confidence intervals are calculated at 0.95 significance level 


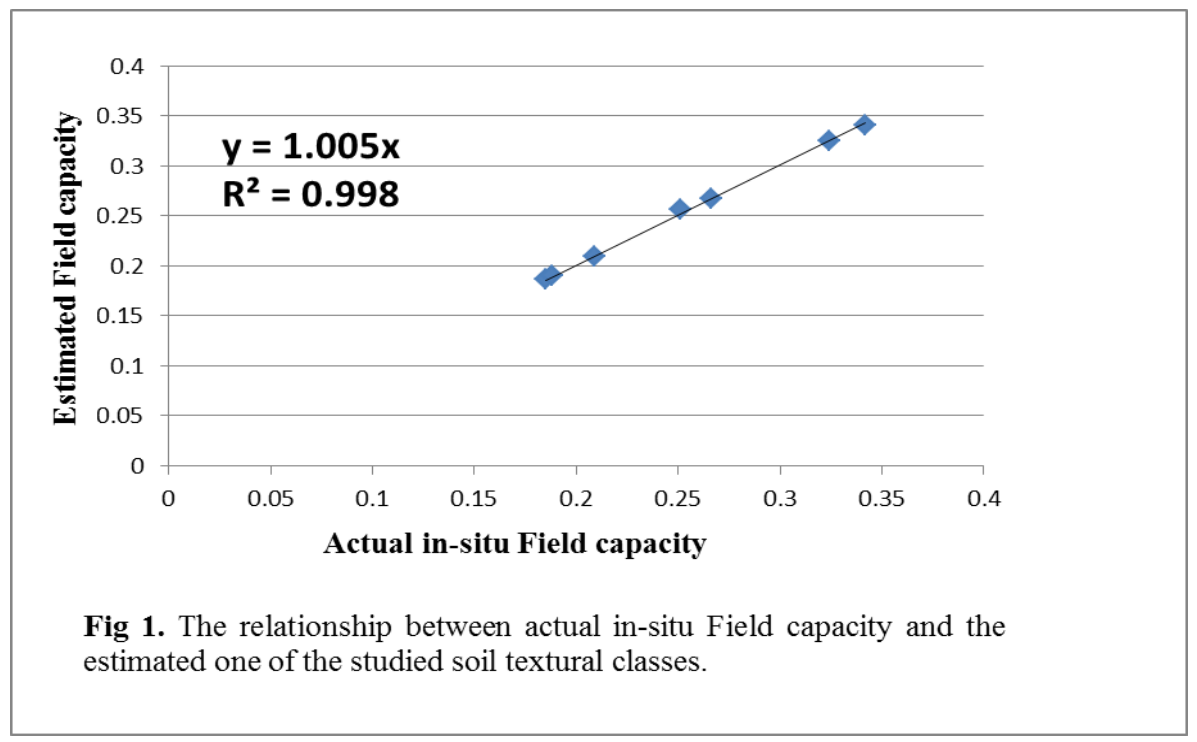

\section{Conclusion}

Under arid conditions, irrigated agriculture is the main way of agricultural production. FC is significantly used in calculating the amount of irrigation water. Unfortunate field methods to determine FC are tedious, labor and time consume, while in laboratory determinations there is no predefined value of pressure that can be used for all soil samples.

Therefore, this trial aimed to find the relationship among FC -in situ- and laboratory determinations of soil moisture content of different soil textural classes under different applied pressures. Results reveal that sand and loamy sand soils reached $\mathrm{FC}$ at about 60 mbar water tension (60 \pm 6 mbar), after 33.11 and 34.22 hours from the end of adding an excess of irrigation water, respectively whereas sandy loam one reached FC at about 86 mbar soil moisture tension after 39.09 hours from the end of irrigation. The soils of other textural classes, reached FC at about 330 mbar soil moisture tension $( \pm 30 \mathrm{mbar})$ and needed $46.99,54.59,81.45$, and 90.01 hours to reach their FC, respectively.

Generally, there is no single and predefined value of applied pressure to get FC using laboratory determination, but it differs according to soil texture, structure, pore size distribution, soil organic matter content and bulk density.

A high significant correlation $(\mathrm{r}=$ 0.9996) was found between actual in-situ FC and the estimated one of the studied soil textural classes. The estimated FC calculated using the coefficient 0.70 for coarse and medium textured soils and 0.85 for heavy textured soils.

\section{References}

Barten, A. P. (1987). The coefficient of determination for regression without a constant term. In The practice of econometrics (pp. 181-189). Springer, Dordrecht.

Cassel, D. K., \& Nielsen, D. R. (1986). Field capacity and available water capacity. Methods of soil analysis: Part 1 Physical and mineralogical methods, 5, 901-926.

Dane, J. H., \& Topp, C. G. (Eds.). (2020). Methods of soil analysis, Part 4: Physical methods (Vol. 20). John Wiley $\&$ Sons.

Galal, M. E. (2000). A new concept of available water in the soil. Annals of Agricultural Science (Cairo), 1(Special), 243-252.

Glossary of Soil Science Terms (1984), Soil Science Glossary Terms Committee, \& 
Soil Science Society of America. ASACSSA-SSSA.

Hillel, D. (2003). Introduction to environmental soil physics. Elsevier.

Israelsen, O. W., \& Wiley, J. (1950). Irrigation principles and practices (Vol. 70, No. 6, p. 479). LWW.

Kirkham, M. B. (2005). Principles of soil and plant water relations Elsevier. Burlington, MA.

Lipsius, K. (2002). Estimating available water capacity from basic soil physical properties: A comparison of common Pedotransfer functions. Unpublished student project. Braunschweig: Braunschweig Technical University.

Nemes, A., Pachepsky, Y. A., \& Timlin, D. J. (2011). Toward improving global estimates of field soil water capacity. Soil Science Society of America Journal, 75(3), 807-812.

Or, D., Wraith, J. M., \& Warrick, A. W. (2002). Soil water content and water potential relationships. Soil physics companion, 1, 49-84.

O'Sullivan, M. F., \& Ball, B. C. (1993). The shape of the water release characteristic as affected by tillage, compaction and soil type. Soil and Tillage Research,25(4), 339-349.

Romano, N., \& Santini, A. (2002). Water retention and storage: Field-field water capacity. p. 723-729. In JH Dane and GC Topp (ed.) Methods of soil analysis. Part
4. SSSA Book Ser. No. 5. SSSA, Madison, WI.

Santra, P., Kumar, M., Kumawat, R. N., Painuli, D. K., Hati, K. M., Heuvelink, G. B. M., \& Batjes, N. H. (2018). Pedotransfer functions to estimate soil water content at field capacity and permanent wilting point in hot Arid Western India. Journal of Earth System Science, 127(3), 1-16.

Shokri, N., Lehmann, P., \& Or, D. (2008). Effects of hydrophobic layers on evaporation from porous media. Geophysical Research Letters, 35(19).

Silva, B. M., Silva, É. A. D., Oliveira, G. C. D., Ferreira, M. M., \& Serafim, M. E. (2014). Plant-available soil water capacity: estimation methods and implications. Revista brasileira de ciência do solo, 38, 464-475.

Singh, R. A. (1980). Soil physical analysis. Kalyani Publishers.

Steel, R. G., \& Torrie, J. H. (1980). Principles and Procedures of Statistics McGraw-Hill Book Co. Inc., New York, 481.

Taylor, S. A., \& Ashcroft, G.L. (1972). Physical edaphology. The physics of irrigated and nonirrigated soils.

Veihmeyer, F. J., \& Hendrickson, A. H. (1949). Methods of measuring field capacity and permanent wilting percentage of soils. Soil science, 68(1), 75-94. 


\section{العلاقة بين التقديرات الموقعية والمعملية للسعة الحقلية بالتربة تحت الظروف الجافة

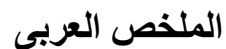 \\ احمد جميل محمد حسين، شيماء حسن عبد الرحمن، محمد السيد جلال، ايمن فريد ابو حديد}

تتناول الدراسة العلاقة بين كل من السعة الحقلية ـ الموقعية ـ و المحتوى الرطوبى للتربة و المقدر معملياً تحت

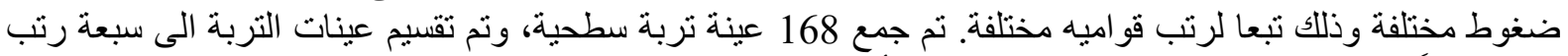

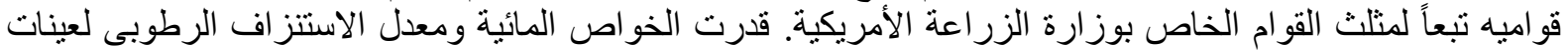

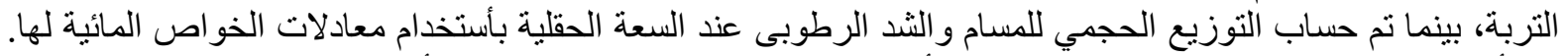

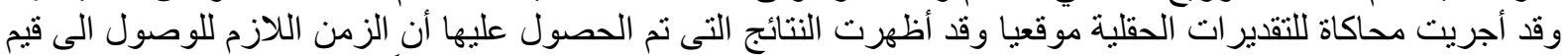

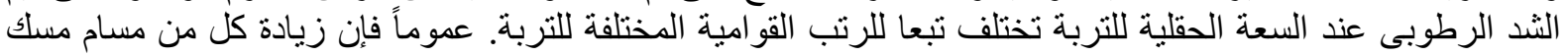

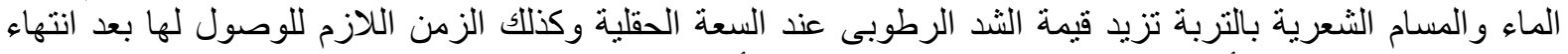

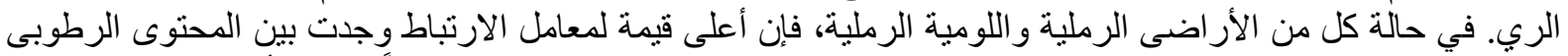

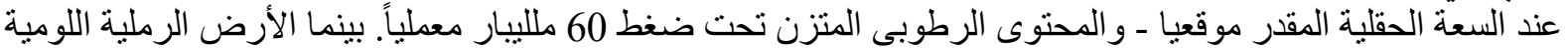

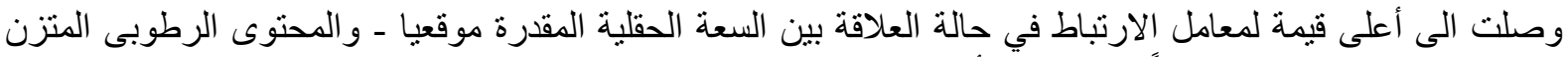

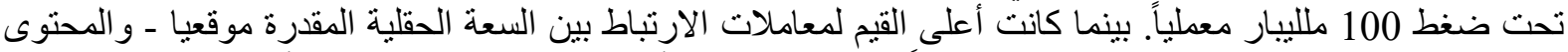

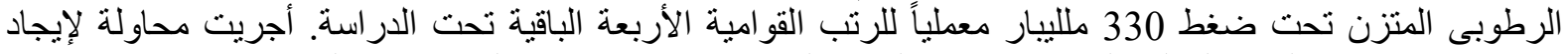

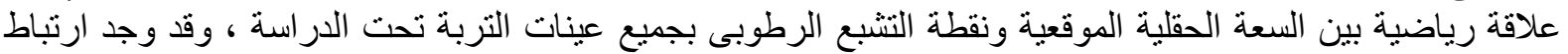

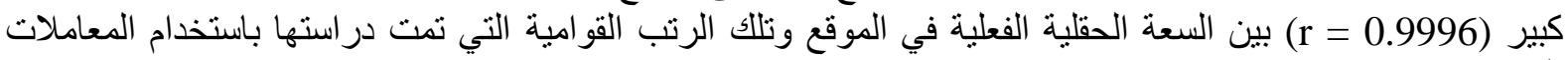

الكلمات المفتاحية: السعة الحقلية، المحتوى المائى للتربة، معدل الاستنز اف الرطوبي، بيانات منحنى الخصائص المائية

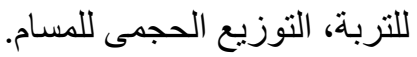

